\title{
Effect of soil-applied lead on mineral contents and biomass in Acer cappadocicum, Fraxinus excelsior and Platycladus orientalis seedlings
}

\author{
Hooman Abbasi ${ }^{(1)}$, \\ Mohammad Reza Pourmajidian (1), \\ Seyed Mohammad Hodjati ${ }^{(1)}$, \\ Asghar Fallah ${ }^{(1)}$, \\ Soumitra Nath ${ }^{(2)}$
}

\begin{abstract}
Phytoremediation is an effective and affordable approach to extract or remove lead from contaminated soil. An understanding of the physiological responses of different species subjected to heavy metal contamination is necessary before considering their use for environmental clean-up. The objective of this study was to assess the effect of lead $(\mathrm{Pb})$ on growth and nutrient uptake in three forest species native to Iran: Cappadocian maple (Acer cappadocicum), European ash (Fraxinus excelsior) and Oriental aborvitae (Platycladus orientalis). The capability of lead uptake in different organs was studied in oneyear-old potted seedlings grown in contaminated soils with $\mathrm{Pb}$ concentration ranging from 100 to $500 \mathrm{mg} \mathrm{kg}^{-1}$ for six months in a nursery. Several phytoextraction parameters such as translocation factor (TF), tolerance index (TI) and bioconcentration factor (BCF) were assessed to investigate the phytoremediation potential of these species. Increasing $\mathrm{Pb}$ application in the soil caused a gradual decrease in dry weight of leaf and shoot of all species, while the dry weight of root remains unaffected. However, such inhibition was less marked in the conifer ( $P$. orientalis) compared to the two broad-leaf species. Phosphorus uptake of all species slightly declined in contaminated soils. Contrastingly, $\mathrm{Pb}$ application did not hinder nitrogen and potassium uptake in seedlings. Atomic absorption thermo electron analysis of $\mathrm{Pb}$-treated plants showed an increasing $\mathrm{Pb}$ accumulation in all plant compartments, although the result was more evident in the tissues of $P$. orientalis. This species also showed the highest values for TF, $\mathrm{TI}$ and $\mathrm{BCF}$, indicating this conifer species as a potential candidate for phytoremediation of lead-polluted soils in Iran.
\end{abstract}

Keywords: Phytoremediation, Seedling Stage, Growth, Nutrient Uptake, Lead Accumulation, Cappadocian Maple, European Ash, Oriental Arborvitae

late the element in their tissues, with no negative effect on their biology (Kibria et al. 2006, Kibria et al. 2007). Identifying an economical, convenient and effective solution for removing or decreasing the harmful elements in polluted soils is necessary.

Phytoremediation technology is a bioremediation strategy that uses plants as filters for accumulating, immobilizing and transforming contaminants to a less harmful form. It generally uses tolerant plants to extract heavy metals from the contaminated soil, and accumulate them in plant tissues (Salt et al. 1998).

Although some herbaceous plants have
(1) Department of Forestry, Faculty of Natural Resources, Sari Agriculture and Natural Resource University, Sari (Iran); (2) Department of Biotechnology, Gurucharan College, Silchar (India)

@ Hooman Abbasi (abbasi_2533@yahoo.com)

Received: Oct 15, 2016 - Accepted: May 04, 2017

Citation: Abbasi H, Pourmajidian MR, Hodjati SM, Fallah A, Nath S (2017). Effect of soilapplied lead on mineral contents and biomass in Acer cappadocicum, Fraxinus excelsior and Platycladus orientalis seedlings. iForest 10: 722-728. - doi: 10.3832/ifor2251-010 [online 2017-07-27]

Communicated by: Claudia Cocozza demonstrated good resistance to heavy metals, tree species with their bigger roots may reach deeper polluted soils, making them more suitable for phytoremediation (Abdul Qados 2015).

Previous studies (Sharma \& Dubey 2005) reported that some cationic channels such as calcium channels are involved in lead uptake in plant tissues. After Pb entry and accumulation in plant tissues, photosynthesis can decrease due to a lower carboxylase activity and negative effects on the metabolites of the carbon reduction cycle (Stiborová et al. 1987). As a non-essential element for plants, lead inhibits not only photosynthesis, changing enzyme activities, hormonal status and respiration, but also the metabolism and mineral nutrient balance, and finally results in decrease of plant growth and production (Päivöke 2002, Sinha et al. 2006, Gopal \& Rizvi 2008). Impairment of nutrient elements leads to decreasing of plant production, and it has been reported that heavy metals, like $\mathrm{Pb}$, can significantly influence the uptake and translocation of some nutrients in plants (Dube et al. 2003, Kopittke et al. 2007, Wang \& Chen 2009). Thus, the imbalance of nutrients and decreasing of plant biomass might be a convenient and reliable symptom of heavy metal toxicity in plants. 
On the other hand, lead accumulation in plant tissues increases with an increase in the exogenous lead level (Lamhamdi et al. 2013). Therefore, plant species with high accumulation ability in their organs are good candidates for heavy metal remediation.

Fewer fast-growing tree species, especially the whole family of Salicaceae, have been considered for metal remediation (Dickinson \& Pulford 2005, Marmiroli et al. 2011, Tognetti et al. 2013). Despite the importance of lead contamination in Iran, it remains unclear as to which native tree species can be used in phytoremediation of polluted soils. Indeed, the phytoremediation potential of many tree species native to Iran has not been investigated hitherto.

The present study focuses on the assessment of selected tree species in lead remediation from contaminated soils by surveying their biomass production and nutrient uptakes under lead pollution. Cappadocian Maple (Acer cappadocicum), European ash (Fraxinus excelsior) and Oriental arborvitae (Platycladus orientalis) are tree species native to Iran with potential interest in phytoremediation. We investigated the effect of lead exposure on mineral content $(\mathrm{N}, \mathrm{P}$, and $\mathrm{K}$ ) as well as the percentage of carbon and $\mathrm{Pb}$ amount in different plant tissues, and their consequences on biomass production in one-year-old seedlings of the above-mentioned species.

\section{Material and methods}

\section{Nursery and plant materials}

The experiment was conducted in the Khoshkedaran nursery, located at the west of Mazandaran province, Iran, approximately $4 \mathrm{~km}$ from Nashtarood city $\left(36^{\circ} 42^{\prime}\right.$ $42^{\prime \prime} \mathrm{N}$ and $51^{\circ} 02^{\prime} 36.9^{\prime \prime} \mathrm{E}$ ). The climate in the region is temperate humid, characterized by an annual average temperature of $16.7^{\circ} \mathrm{C}$ and average annual precipitation of $1233.27 \mathrm{~mm}$. A total of 180 , one-year-old seedlings of Acer cappadocicum, Fraxinus excelsior and Platycladus orientalis were planted in individual pots. The pots with the 3 - $\mathrm{kg}$ capacity were filled with sandyclay-loamy soil (46.2: 26.4: 24.5 ), bearing $39.5 \%$ moisture, $\mathrm{pH} 7.4$ and EC $0.26 \mathrm{ds} \mathrm{m}^{-1}$. Percentage of organic carbon, organic matter and total nitrogen $(\mathrm{N})$ in the soil was $1.35,2.322$ and $0.11 \%$, respectively. Besides,

Tab. 1 - One-way ANOVA of plant biomass of the three species grown in lead contaminated soil. Only $\mathrm{F}$ values are presented. $(*)$ : $p<0.05 ;(* *)$ : $p<0.01$; (ns): not significant.

\begin{tabular}{lcrl}
\hline $\begin{array}{l}\text { Bio- } \\
\text { mass }\end{array}$ & $\begin{array}{c}P . \\
\text { orientalis }\end{array}$ & $\begin{array}{c}F . \\
\text { excelsior }\end{array}$ & $\begin{array}{c}\text { A. } \\
\text { cappado- } \\
\text { cicum }\end{array}$ \\
\hline Leaf & $17.3^{* *}$ & $4.319^{* *}$ & $8.652^{* *}$ \\
Stem & $1.307^{\text {ns }}$ & $2.916^{*}$ & $3.24^{*}$ \\
Root & $0.428^{\text {ns }}$ & $9.209^{*}$ & $1.667^{\text {ns }}$ \\
Total & $5.04^{* *}$ & $10.159^{*}$ & $4.882^{* *}$ \\
\hline
\end{tabular}

the amount of absorbable phosphorus ( $P$ ) and potassium (K) was 18 and $146 \mathrm{mg} \mathrm{kg}^{-1}$. The $\mathrm{Pb}$ content of the untreated soil in the nursery was found to be $12.7 \mathrm{mg} \mathrm{kg}^{-1}$.

\section{Lead contamination treatments}

Soil samples were first contaminated with six different concentrations of lead ( 0 , 100, 200, 300, 400 and $\left.500 \mathrm{mg} \mathrm{kg}^{-1}\right)$, which was used in the form of $\mathrm{Pb}\left(\mathrm{NO}_{3}\right)_{2}$. All the pots were labeled to distinguish between treatments and then randomly arranged to avoid possible bias due to their location within the nursery. The treated seedlings grew under natural environment during the growth season (six months). The experiment was carried out in 10 replicates for each lead contamination treatment. Overall, 60 seedlings were used for each species. All treated seedlings were irrigated based on $100 \%$ field capacity once every three days.

\section{Measurement of growth and biomass}

At the end of the experiment, all seedlings were harvested and the leaf, stem and root were separated. To obtain the dry weight of each plant part, samples were oven dried at $80{ }^{\circ} \mathrm{C}$ until constant weight was achieved. Finally, the dry weight of each seedling was recorded.

\section{Measurement of $\mathrm{Pb}$ in root, stem and leaf}

Lead analysis in plant tissues was performed by atomic absorption thermo electron (ICE ${ }^{\mathrm{TM}} 3000$ Series AAS, ThermoFischer Scientific, Waltham, MA, USA) according to a modified manufacturer's method. For the sample preparation, $0.5 \mathrm{~g}$ of dried ground plant tissue was digested by $3.5 \mathrm{ml}$ of $\mathrm{H}_{2} \mathrm{SO}_{4}$ and ashed in the furnace for $30 \mathrm{~min}$ utes at $250{ }^{\circ} \mathrm{C}$. Finally, the ash was dissolved in $\mathrm{HCl}$ and lead content was determined.

\section{Measurement of nutrients in root, stem and leaf}

Ground plant samples were oven dried at $65^{\circ} \mathrm{C}$ and then digested with a mixture of $\mathrm{H}_{2} \mathrm{SO}_{4}, \mathrm{H}_{2} \mathrm{O}_{2}$ and lithium sulfate for the determination of $\mathrm{N}, \mathrm{P}$ and $\mathrm{K}$ (Allen et al. 1986). The concentration of the nutrients in the digest was measured by an atomic absorption spectrophotometer (ICE ${ }^{\mathrm{TM}} 3000$ Series AAS). Micro-Kjeldahl method (Ryan et al. 2007) was used for the determination of nitrogen. Phosphorus was determined by vanadomolybdo phosphoric yellow color method in the nitric acid system (Ryan et al. 2007) and potassium was measured by a flame photometer (Kibria et al. 2010).

\section{Phytoextraction parameters}

Phytoextraction parameters such as translocation factor (TF), tolerance index ( $\mathrm{TI}$ ) and bioconcentration factor (BCF) were examined (Wilkins 1978, Zayed et al. 1998, Mattina et al. 2003, Yoon et al. 2006). The TF is the capacity of a plant to transfer metal from its roots to shoots. TI is based on the dry weight of the plant, whereas BCF is an index commonly used to determine the potential of a plant for remediation of heavy metals from contaminated soils to its root (Arifin et al. 2012). In the current study, the TI, TF (Yoon et al. 2006) and BCF (Arifin et al. 2012) values for lead were calculated as follows (eqn. 1, eqn. 2, eqn. 3):

$$
\begin{aligned}
& T I=D W_{P b} / D W_{c} \\
& T F=C_{\text {shoot }} / C_{\text {root }} \\
& B C F=C_{\text {root }} / C_{\text {soil }}
\end{aligned}
$$

where $D W_{P b}$ and $D W_{c}$ are the dry weights of the seedlings grown in contaminated soil and control, respectively, and $C_{\text {shoot }}$, $\mathrm{C}_{\text {root }}$ and $\mathrm{C}_{\text {soil }}$ are the concentrations of lead in shoots, roots and soil, respectively.

\section{Statistical analysis}

The experiment was performed in a completely randomized design. Biomass data was analyzed by one-way ANOVA, while data of nutrient elements and $\mathrm{Pb}$ adsorption were analyzed by two-way ANOVA. Shapiro-Wilk's and Levene's test were applied to test for normality and variance homogeneity across treatments, respectively. All statistical analyses were carried out using SPSS $^{\oplus}$ ver. 16.0 (IBM, Armonk, NY, USA). Differences among treatments were tested using the Duncan's test with $a=0.05$.

\section{Results}

\section{Seedling mortality}

Seedling mortality was not observed after the application of lead in the soil. Symptoms of leaf senescence were less evident in A. cappadocicum, whereas other species had sufficient vitality.

\section{Dry biomass}

Lead contamination in the soil showed a negative effect on dry biomass in all the treated seedlings of $A$. cappadocicum, $F$. excelsior, P. orientalis (Tab. 1), but the level of adverse effects was different for each species and their parts (Fig. 1, Fig. 2 and Fig. 3). A. cappadocicum seedlings exposed to moderate and high concentrations of $\mathrm{Pb}$ (from 200 to $500 \mathrm{mg} \mathrm{kg}^{-1}$ ) showed a significant decrease in leaf and stem biomass, whereas the dry weight of roots did not show any considerable difference across $\mathrm{Pb}$ treatments (Fig. 1). The total biomass of the species was significantly affected by soil $\mathrm{Pb}$ at concentration $\geq 200 \mathrm{mg} \mathrm{kg}^{-1}$.

Exposure of $F$. excelsior seedlings to 500 $\mathrm{mg} \mathrm{kg}{ }^{-1}$ of soil $\mathrm{Pb}$ concentration declined the dry biomass of shoots and leaves (Fig. 2), while no significant changes were detected for low and moderate concentrations of $\mathrm{Pb}$. Root biomass of seedlings of this species was significantly affected at $400 \mathrm{mg} \mathrm{kg}^{-1}$ of soil $\mathrm{Pb}$ concentration, while root biomass at $500 \mathrm{mg} \mathrm{kg}^{-1}$ of soil $\mathrm{Pb}$ con- 
Fig. 1 - Dry biomass in root, shoot, and leaf of Cappadocian Maple (Acer cappadocicum) seedlings grown at different $\mathrm{Pb}$ concentrations in the soil. Control seedlings (" 0 " treatment) received $12 \mathrm{mg} \mathrm{kg}^{-1} \mathrm{~Pb}$ from untreated soils in the nursery. Different letters indicate significant differences $(P<0.05)$ among $P b$ treatments after Duncan's tests.

Fig. 2 - Dry biomass in root, shoot, and leaf of European ash (Fraxinus excelsior) seedlings grown at different $\mathrm{Pb}$ concentrations in the soil. Control seedlings ("o" treatment) received $12 \mathrm{mg} \mathrm{kg}^{-1} \mathrm{~Pb}$ from untreated soils in the nursery. Different letters indicate significant differences $(P<0.05)$ among $P b$ treatments after Duncan's tests.

Fig. 3 - Dry biomass in root, shoot, and leaf of Oriental arborvitae (Platycladus orientalis) seedlings grown at different $\mathrm{Pb}$ concentrations in the soil. Control seedlings ("o" treatment) received $12 \mathrm{mg} \mathrm{kg}^{-1} \mathrm{~Pb}$ from untreated soils in the nursery. Different letters indicate significant differences $(P<0.05)$ among $P b$ treatments after Duncan's tests.
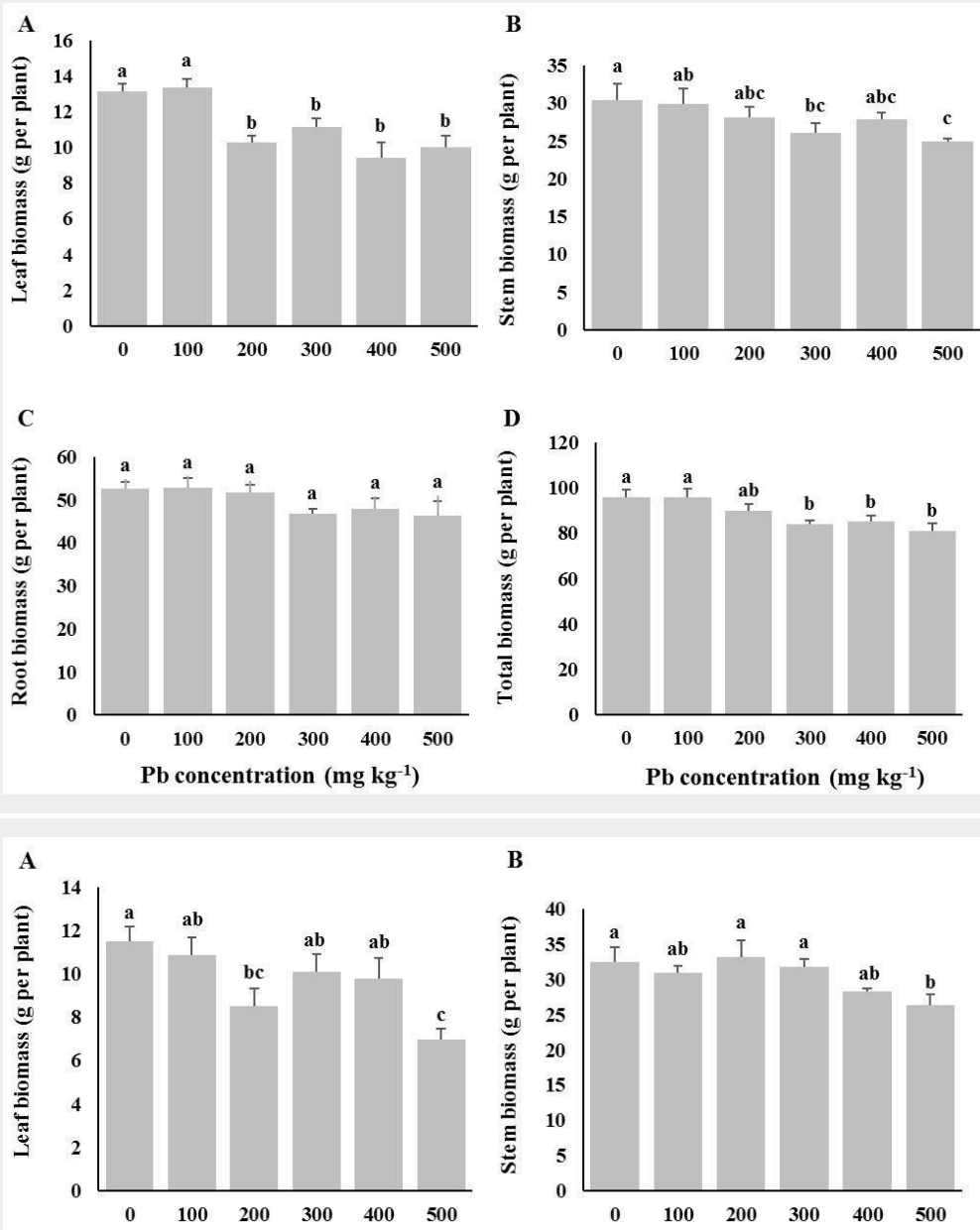

B
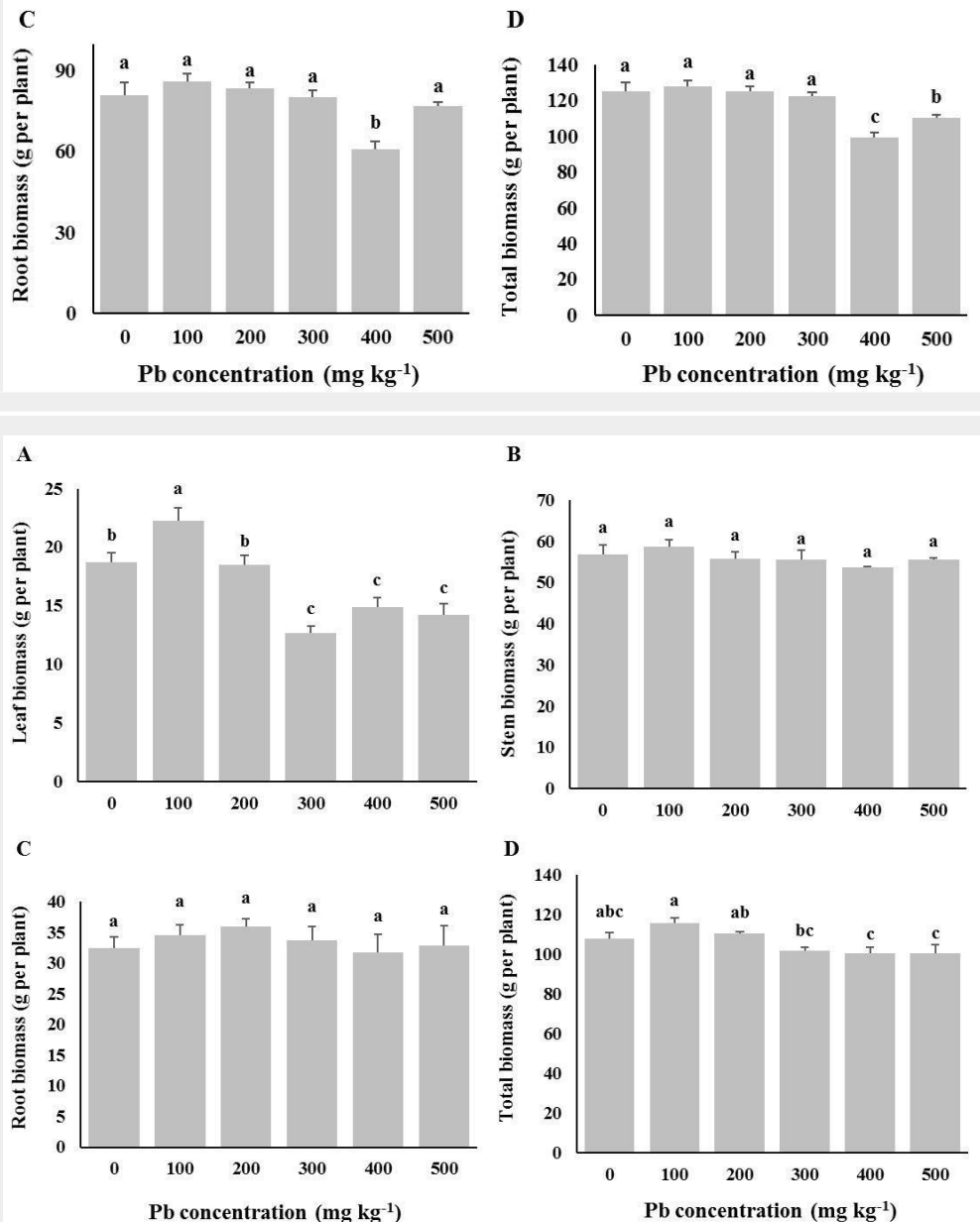

D

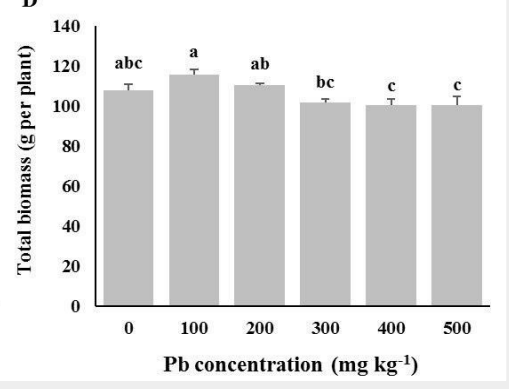


Tab. 2 - Two-way ANOVA of nutrient content and $\mathrm{Pb}$ uptake in plant organs of the three species subjected soil lead contamination. Only $\mathrm{F}$ values are presented. $(* *)$ : $\mathrm{p}<0.01$.

\begin{tabular}{lcccc}
\hline Species & Element & $\begin{array}{c}\text { Plant organ } \times \\
\text { Pb treatment }\end{array}$ & Pb treatment & Plant organ \\
\hline Acer & $\mathrm{N}$ & $7.28^{* *}$ & $13.56^{* *}$ & $11.152^{* *}$ \\
cappadocicum & $\mathrm{P}$ & $8.92^{* *}$ & $7.25^{* *}$ & $308.7^{* *}$ \\
& $\mathrm{~K}$ & $3.39^{* *}$ & $5.38^{* *}$ & $640.8^{* *}$ \\
Fraxinus & $\mathrm{Pb}$ & $31.48^{* *}$ & $123.12^{* *}$ & $438.59^{* *}$ \\
excelsior & $\mathrm{N}$ & $5.00^{* *}$ & $7.97^{* *}$ & $1949.3^{* *}$ \\
& $\mathrm{P}$ & $12.67^{* *}$ & $26.64^{* *}$ & $501.08^{* *}$ \\
& $\mathrm{~K}$ & $6.22^{* *}$ & $17.2^{* *}$ & $873.2^{* *}$ \\
Platycladus & $\mathrm{Pb}$ & $45.3^{* *}$ & $104.08^{* *}$ & $794.73^{* *}$ \\
orientalis & $\mathrm{N}$ & $2.04^{* *}$ & $8.92^{* *}$ & $699.1^{* *}$ \\
& $\mathrm{P}$ & $5.21^{* *}$ & $23.27^{* *}$ & $334.38^{* *}$ \\
& $\mathrm{~K}$ & $0.73^{\mathrm{ns}}$ & $2.69^{*}$ & $19.21^{* *}$ \\
& $\mathrm{~Pb}$ & $111.83^{* *}$ & $329.71^{* *}$ & $1467.73^{* *}$ \\
\hline
\end{tabular}

Fig. 4 - $\mathrm{Pb}$ concentration ( $\mathrm{mg}$ $\mathrm{kg}^{-1}$ or $\mathrm{ppm}$ ) in different tissues of Cappadocian Maple (Acer cappadocicum - A), European ash (Fraxinus excelsior -

B) and Oriental arborvitae

(Platycladus orientalis - C) seedlings at the end of growing season. Control seedlings ("o" treatment) received 12 $\mathrm{mg} \mathrm{kg}^{-1} \mathrm{~Pb}$ from untreated soils in the nursery. Different letters indicate significant differences $(P<0.05)$ among treatments after Duncan's test.
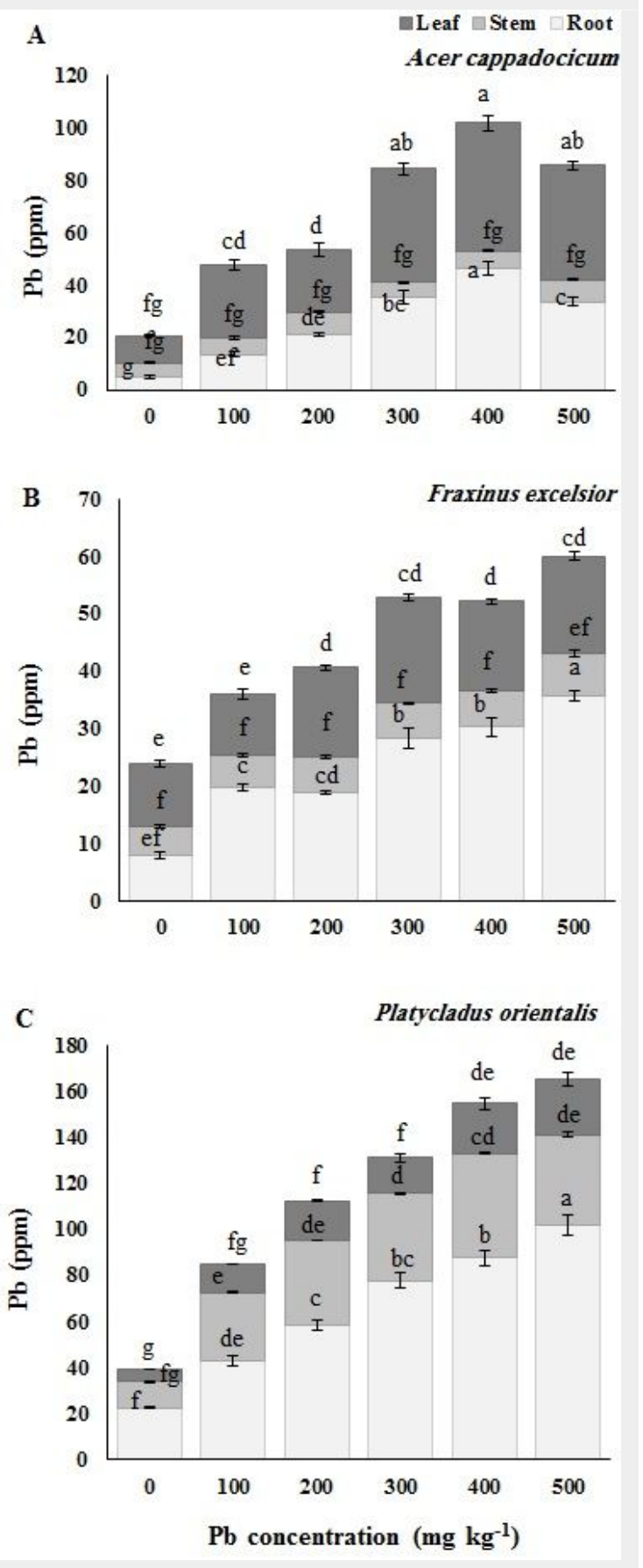

centration was not significantly different from that observed in the control. As expected, the minimum total biomass in this species was observed for seedlings subjected to 400 and $500 \mathrm{mg} \mathrm{kg}^{-1} \mathrm{~Pb}$ in the soil.

An inhibitory effect of $\mathrm{Pb}$ on leaf biomass of $P$. orientalis seedlings was observed, compared to control seedlings, while the effect of $\mathrm{Pb}$ contamination on stem and root was not significant. On the other hand, the total dry biomass of the species did not show considerable modifications in response to increasing $\mathrm{Pb}$ concentrations (Fig. 3).

\section{Lead uptake and nutrient element content}

The results of two-way ANOVA indicated that $\mathrm{Pb}$ uptake and $\mathrm{N}, \mathrm{P}$ and $\mathrm{K}$ content in seedlings of all species were significantly different among $\mathrm{Pb}$ treatments and different plant organs (Tab. 2). Also, the interaction effect of $\mathrm{Pb}$ treatment and plant organ was significant for all species and element contents, except for K in Platycladus orientalis.

Concentrations of lead in leaf, stem and root of seedlings of each species across the different $\mathrm{Pb}$ treatments are shown in Fig. 4. The results showed that the $\mathrm{Pb}$ concentration in controls were lowest in Cappadocian maple (A. cappadocicum) and highest in Oriental arborvitae ( $P$. orientalis). The results of Duncan's test clearly indicated that the application of lead to soil significantly increased the concentration of this element in the roots, shoots and leaves, as compared with the relative control, in all the studied species. Total lead concentrations reached $60 \mathrm{mg} \mathrm{kg}^{1}$ dry matter in $\mathrm{F}$. excelsior seedlings and $120 \mathrm{mg} \mathrm{kg}^{1}$ dry matter in P. orientalis at $500 \mathrm{mg} \mathrm{kg}^{-1} \mathrm{~Pb}$ in the soil, while the highest amount of lead for A. cappadocicum seedlings was recorded at soil $\mathrm{Pb}$ concentration of $400 \mathrm{mg} \mathrm{kg}^{-1}$, reaching $100 \mathrm{mg} \mathrm{kg}^{1}$ dry matter. The lowest content of lead was recorded in stems of $A$. cappadocicum and $F$. excelsior and in the leaves of $P$. orientalis. It has also been observed that only $P$. orientalis could accumulate a high amount of $\mathrm{Pb}$ in the stem.

Comparison of macroelements (N, P and $\mathrm{K})$ mean content in different plant organs among $\mathrm{Pb}$ treatments is represented in Fig. 5. The results of Duncan's test revealed a negligible difference among treatments in the amount of nitrogen $(\mathrm{N})$ in various tissues of all the three species (Fig. 5A-B-C). In contrast, total phosphorus $(\mathrm{P})$ content significantly declined with increasing lead supply in all the species (Fig. 5D-E-F). The decrease in $\mathrm{P}$ concentration in the different organs of $P$. orientalis was more prominent than in the other species, whereas the $K$ content was stable in various tissues of the three species across $\mathrm{Pb}$ treatments (Fig. $5 \mathrm{G}-\mathrm{H}-\mathrm{I})$.

\section{Phytoextraction parameters}

Lead contamination in the soil significant- 
Fig. 5 - Macro-element content (nitrogen: A, B, C; phosphorus: D,E,F; potassium: G, $\mathrm{H}, \mathrm{I}$ ) in leaves, stem and roots of Cappadocian Maple (Acer cappadocicum - top), European ash (Fraxinus excelsior - middle) and Oriental arborvitae (Platycladus orientalis - bottom) seedlings grown at different $\mathrm{Pb}$ concentrations in the soil $(0,100$, 200, 300, 400, $500 \mathrm{mg} \mathrm{kg}^{-1}$ ). Control seedlings ("o" treatment) received $12 \mathrm{mg}$ $\mathrm{kg}^{-1} \mathrm{~Pb}$ from untreated soils in the nursery. Different letters indicate significant differences $(P<0.05)$ among treatments after Duncan's test.

ly affected the Translocation Factor (TF), Tolerance Index $(\mathrm{TI})$ and Bio-Concentration Factor (BCF - Tab. 3). Lead contamination decreased the seedling TF in all the species (Fig. 6). Interestingly, low level of contamination (100 $\mathrm{mg} \mathrm{kg}^{-1} \mathrm{~Pb}$ treatment) resulted in a considerable improvement of $\mathrm{TI}$ in the seedlings of $P$. orientalis. TI values ranged
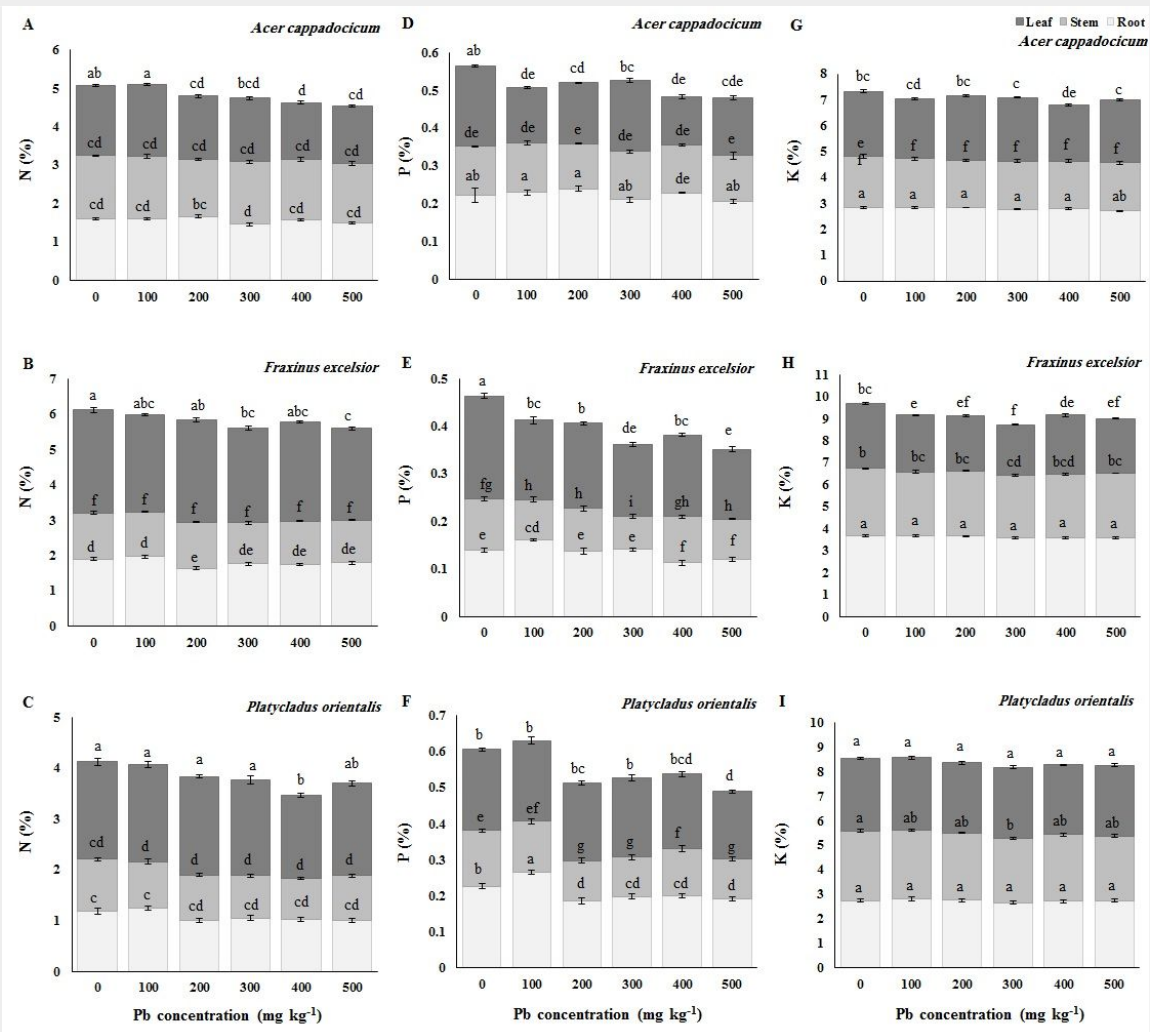

Tab. 3 - One-way ANOVA of phytoextraction parameters of the three studied species under different lead contamination levels. Only F values are presented. (**): $p<0.01$.

\begin{tabular}{lccc}
\hline Parameter & $\begin{array}{c}\text { Platycladus } \\
\text { orientalis }\end{array}$ & $\begin{array}{c}\text { Fraxinus } \\
\text { excelsior }\end{array}$ & $\begin{array}{c}\text { Acer } \\
\text { cappadocicum }\end{array}$ \\
\hline Translocation factor (TF) & $17.017^{* *}$ & $29.39^{* *}$ & $32.529^{* *}$ \\
Tolerance index (TI) & $5.04^{* *}$ & $10.159^{* *}$ & $6.103^{* *}$ \\
Bioconcentration factor (BF) & $127.16^{* *}$ & $280.37^{* *}$ & $151.64^{* *}$ \\
\hline
\end{tabular}

Fig. 6 - Effect of lead contamination in the soil on Translocation Factor ( $\mathrm{TF}-\mathrm{A}, \mathrm{D}, \mathrm{G})$, Tolerance Index ( $\mathrm{TI}-$ $B, E, H)$ and Bioconcentration Factor $(B C F-C, F, I)$ in seedlings of the three studied species (Acer cappadocicum - top; Fraxinus excelsior - middle; Platycladus orientalis bottom). Control seedlings (" 0 " treatment) received $12 \mathrm{mg} \mathrm{kg}^{-1} \mathrm{~Pb}$ from untreated soils in the nursery. Different letters indicate significant differences $(P<0.05)$ among treatments after Duncan's test.
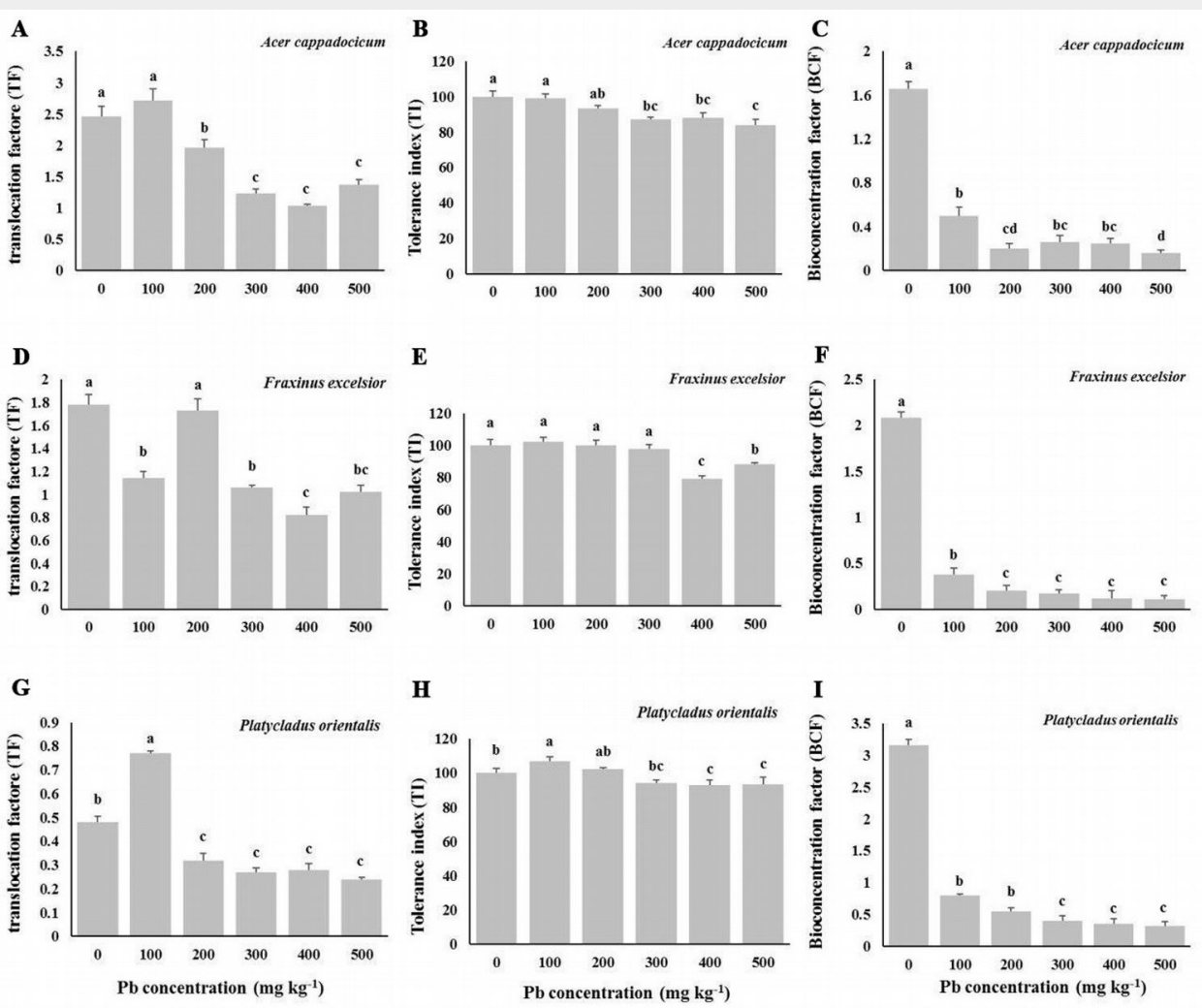
from 80 to 100 in all the treatments (Fig. $6 \mathrm{~B}-\mathrm{E}-\mathrm{H})$. The lowest values of $\mathrm{TI}$ were recorded in the 400 and $500 \mathrm{mg} \mathrm{kg}^{-1} \mathrm{~Pb}$ treatments in all the species, with the minimum value $(\mathrm{Tl}=80)$ recorded for $F$. excelsior at $400 \mathrm{mg} \mathrm{kg}^{-1} \mathrm{~Pb}$. Maximum TI was found in the control and sometimes in the lowlevel contamination treatments, which showed no significant difference with their respective controls at $5 \%$ level.

The highest mean value of BCF was estimated for the control seedlings, while the lowest at $500 \mathrm{mg} \mathrm{kg}^{-1} \mathrm{~Pb}$ (Fig. 6C-F-I). Increasing the $\mathrm{Pb}$ amount in soil significantly decreased BCF across all the studied species. The highest value of BCF (3.16) was observed in control seedlings of $P$. orientalis.

\section{Discussion}

Growth disorders and biomass reductions are commonly observed in plants subjected to high levels of metal contamination (Panich-Pat et al. 2010). The decline in plant growth occurs due to the adverse effect of heavy metals on cell division and may be due to their influence on DNA, RNA or protein metabolism (Auda \& Ali 2010). In this study, total dry biomass of seedlings declined by 14,8 and $5 \%$ for A. cappadocicum, $F$. excelsior and $P$. orientalis, respectively, when exposed to lead at high concentration (500 mg kg-1 Pb). Malar et al. (2014) reported that plant biomass is a good indicator of plant growth performance in presence of heavy metals. Accordingly, we observed an adverse effect of lead on seedling growth, which became more evident at the higher concentrations of lead in the soil. Among the studied species, growth inhibition was lower in $P$. orientalis compared to the other two species, while seedling mortality was not observed in any species. Roots of studied tree species seemed to be more tolerant to lead pollution than shoots and leaves. Indeed, we observed that the dry biomass of seedling roots was not significantly affected by increasing $\mathrm{Pb}$ concentrations in the soil, whereas leaf biomass was more sensitive to the lead contamination.

Lamhamdi et al. (2013) reported that the decrease of plant dry weight can be essentially attributed to a deficiency of some nutrient elements, especially $\mathrm{N}, \mathrm{P}$ and $\mathrm{K}$, resulting from the inhibition of their uptake under $\mathrm{Pb}$ exposure. In this study, lead contamination significantly affected $\mathrm{N}, \mathrm{P}$ and $\mathrm{K}$ adsorption, but the contamination could not remarkably inhibit the uptake of essential elements, so much as $P$ content in $P$. orientalis seedlings varied across treatments by a negligible amount. Contrastingly, Akinci et al. (2010) and Päivöke (2002) observed a negative correlation between $\mathrm{P}$ uptake and lead concentration in the soil.

Our results clearly showed that a remarkable deficiency of $\mathrm{N}, \mathrm{P}$ and $\mathrm{K}$ did not occur when seedlings were subjected to lead contamination, though a slight reduction in plant biomass was observed, particularly for broad-leaved species (A. cappadocicum and $F$. excelsior). Lead contamination results in phytotoxicity primarily by inactivating enzymes and causing physiological changes (Rascio \& Navari-Izzo 2011, Santana et al. 2012). Therefore, we conclude that the presence of the heavy metal $\mathrm{Pb}$ in soil can have some inhibitory effects on physiological and biochemical parameters of the three studied species. Lead can create physical barriers and disturb the physiology of root absorption, thereby inhibiting the uptake of many essential ions (Godbold \& Kettner 1991, Deng et al. 2009, Fahr et al. 2013). $\mathrm{Pb}$ toxicity disrupts the uptake of other macroelements ( $\mathrm{Ca}, \mathrm{Mg}$ and $\mathrm{Na}$ ) or microelements ( $\mathrm{Fe}, \mathrm{Cu}$, and $\mathrm{Zn}$ ), which are essential for plant growth (Shahid et al. 2012, Callahan et al. 2016).

The observed ability of $\mathrm{Pb}$ bioaccumulation suggests the existence of an efficient hyper-accumulation mechanism in the studied species, which allows for removal of the heavy metal from contaminated soils (Malar et al. 2014). Our findings clearly showed the ability of $P$. orientalis in phytoremediation of highly-contaminated soil. Furthermore, the amount of $\mathrm{Pb}$ accumulated by $P$. orientalis was more than two times as compared to A. cappadocicum and F. excelsior.

The Translocation Factor (TF) reflects the capacity of a plant to transfer metal from its roots to shoots (Ebrahimi 2013). We found that TF declined for all species in response to increasing levels of $\mathrm{Pb}$ concentration in soil. Interestingly, TF significantly increased in $P$. orientalis when seedlings were subjected to $100 \mathrm{mg} \mathrm{kg}^{-1} \mathrm{~Pb}$. The Tolerance Index $(\mathrm{TI})$ is assumed to equal 100 when there is no influence of the treatment on growth, whereas it takes values higher or lower than 100 in the case of positive or negative effects of the treatment, respectively (Zaier et al. 2010). We observed that TI values slightly decrease in all the species with increasing soil $\mathrm{Pb}$ contamination, the lowest $\mathrm{TI}$ values being for $F$. excelsior at 400 and $500 \mathrm{mg} \mathrm{kg}^{-1} \mathrm{~Pb}$. On the other side, TI for $P$. orientalis was close to 100 even when the plant was subjected to a high concentration of the heavy metal.

Bioconcentration factor (BCF) is defined as the ratio of heavy metal concentration in plant organs to that in the soil (Malik et al. 2010). In this study, BCF varied across species and $\mathrm{Pb}$ concentrations in the soil, with values $<1$ in all treatments except in control. BCF decreased with increasing $\mathrm{Pb}$ concentration in the soil, which suggests a restriction in soil-root transfer at higher $\mathrm{Pb}$ concentrations in the soil (Justin et al. 2011). Although $B C F$ was $<1$ in all the three studied species, $P$. orientalis was more successful in the extraction of lead from the soil.

\section{Conclusion}

Our findings indicate that lead treatments even at high concentrations do not induce a significant disturbance in $\mathrm{N}, \mathrm{P}$ and $\mathrm{K}$ uptake by plants. Moreover, we observed negative effects of lead contamination on plant production in all the three species.

The lack of mortality and the lack of a significant reduction in growth suggest that the studied species are promising in phytoremediation of lead-polluted soils, although Oriental arborvitae (Platycladus orientalis) appears to be far more resistant to lead contamination. Indeed, this conifer showed a larger $\mathrm{Pb}$ uptake and accumulation in tissues, while nutrient uptake, growth and biomass production did not change considerably. Further, seedlings of $P$. orientalis showed higher TI values compared to the two broadleaf species, and a higher lead translocation from root to stem, according to TF and BCF. Finally, the two broadleaves showed a lower lead accumulation in their stems as compared to the conifer species.

Therefore, it is concluded that Platycladus orientalis exhibits more relative resistance to lead contamination and is more suitable for phytoremediation of lead-polluted soils as compared to Acer cappadocicum and Fraxinus excelsior. Further studies are need ed to explore its response to more severe contaminations under prolonged exposure time.

\section{References}

Abdul Qados AMA (2015). Phytoremediation of $\mathrm{Pb}$ and $\mathrm{Cd}$ by native tree species grown in the Kingdom of Saudi Arabia. Agriculture and Biology Journal of North America 3 (1): 22-34. [online] URL: http://www.scihub.org/ABJNA/PD F/2015/1/ABJNA-6-1-8-21.pdf

Akinci IE, Akinci S, Yilmaz K (2010). Response of tomato (Solanum lycopersicum L.) to lead toxicity: growth, element uptake, chlorophyll and water content. African Journal of Agricultural Research 5 (6): 416-423. [online] URL: http:// www.academicjournals.org/journal/AJAR/articl e-abstract/A2163F427998

Allen S, Grimshaw H, Rowland A (1986). Chemical analysis. In: "Methods in Plant Ecology ( $2^{\text {nd }}$ edn)" (Moore PD, Chapman SB eds). Blackwell Scientific Publication, Oxford, London, pp. 285344.

Arifin A, Parisa A, Hazandy AH, Mahmud TM, Junejo N, Fatemeh A, Mohsen S, Wasli ME, Majid NM (2012). Evaluation of cadmium bioaccumulation and translocation by Hopeaodorata grown in a contaminated soil. African Journal of Biotechnology 11 (29): 7472-7482. [online] URL: http://www.ajol.info/index.php/ajb/article/ view/102394

Auda MA, Ali EELS (2010). Cadmium and Zinc toxicity effects on growth and mineral nutrients of carrot (Daucus carota). Pakistan Journal of Botany 42: 341-351. [online] URL: http:// www.pakbs.org/pjbot/PDFs/42(1)/PJB42(1)341.p df

Callahan DL, Hare DJ, Bishop DP, Doble PA, Roessner U (2016). Elemental imaging of leaves from the metal hyperaccumulating plant Noccaea caerulescens shows different spatial distribution of $\mathrm{Ni}, \mathrm{Zn}$ and $\mathrm{Cd}$. RSC advances 6 (3): 2337-2344. - doi: 10.1039/C5RA23953B 
Deng $\mathrm{H}$, Ye ZH, Wong MH (2009). Lead, zinc and iron $\left(\mathrm{Fe}^{2+}\right)$ tolerances in wetland plants and relation to root anatomy and spatial pattern of ROL. Environmental and Experimental Botany 65 (2): 353-362. - doi: 10.1016/j.envexpbot.2008. 10.005

Dickinson NM, Pulford ID (2005). Cadmium phytoextraction using short-rotation coppice Salix: the evidence trail. Environment International 31 (4): 609-613. - doi: 10.1016/j.envint.2004.10.013 Dube B, Tewari K, Chatterjee J, Chatterjee C (2003). Excess chromium alters uptake and translocation of certain nutrients in Citrullus. Chemosphere 53 (9): 1147-1153. - doi: 10.1016/ So045-6535(03)00570-8

Ebrahimi M (2013). Effect of EDTA application on heavy metals uptake and germination of Echinochloa crus galli (L.) Beave in contaminated soil. International Journal of Agriculture and Crop Sciences 6 (4): 197-202.

Fahr M, Laplaze L, Bendaou N, Hocher V, El Mzibri M, Bogusz D, Smouni A (2013). Effect of lead on root growth. Frontiers in Plant Science 4 (175): 1-7. [online] URL: http://www.ncbi.nlm. nih.gov/pmc/articles/PMC3674728/

Godbold D, Kettner C (1991). Lead influences root growth and mineral nutrition of Picea abies seedlings. Journal of Plant Physiology 139 (1): 95-99. - doi: 10.1016/S0176-1617(11)80172-0

Gopal R, Rizvi AH (2008). Excess lead alters growth, metabolism and translocation of certain nutrients in radish. Chemosphere 70 (9): 1539-1544. - doi: 10.1016/j.chemosphere.2007. 08.043

Justin V, Majid N, Islam MM, Abdu A (2011). Assessment of heavy metal uptake and translocation in Acacia mangium for phytoremediation of cadmium contaminated soil. Journal of Food, Agriculture and Environment 9: 588-592. [online] URL: http://world-food.net/download/ journals/2011-issue_2/e26.pdf

Kibria M, Osman K, Ahmed MJ (2006). Cadmium and lead uptake by rice (Oryza sativa L.) grown in three different textured soils. Soil and Environment 25 (2): 70-77.

Kibria M, Osman K, Ahmed M (2007). Cadmium and lead uptake by radish (Raphanus sativus L.) grown in three different textured soils. Soil and Environment 26 (2): 106-114. [online] URL: http://agris.fao.org/agris-search/search.do?rec ordID=PK2008001164

Kibria M, Maniruzzaman M, Islam M, Osman K (2010). Effects of soil-applied lead on growth and partitioning of ion concentration in Spinacea oleracea L. tissues. Soil and Environment 29 (1): 1-6. [online] URL: http://www.researchga te.net/publication/288094378

Kopittke PM, Asher CJ, Kopittke RA, Menzies NW (2007). Toxic effects of $\mathrm{Pb}^{2+}$ on growth of cowpea (Vigna unguiculata). Environmental Pol- lution 150 (2): 280-287. - doi: 10.1016/j.envpol. 2007.01.011

Lamhamdi M, El Galiou O, Bakrim A, NóvoaMuñoz JC, Arias-Estévez M, Aarab A, Lafont R (2013). Effect of lead stress on mineral content and growth of wheat (Triticum aestivum) and spinach (Spinacia oleracea) seedlings. Saudi Journal of Biological Sciences 20 (1): 29-36. doi: 10.1016/j.sjbs.2012.09.001

Malar S, Vikram SS, Favas PJ, Perumal V (2014). Lead heavy metal toxicity induced changes on growth and antioxidative enzymes level in water hyacinths [Eichhornia crassipes (Mart.)]. Botanical Studies 57 (1): 1-11. [online] URL: http://as-botanicalstudies.springeropen.com/ar ticles/10.1186/s40529-014-0054-6

Malik RN, Husain SZ, Nazir I (2010). Heavy metal contamination and accumulation in soil and wild plant species from industrial area of Islamabad, Pakistan. Pakistan Journal of Botany 42: 291-301. [online] URL: http://www.pakbs.org/pj bot/PDFs/42(1)/PJB42(1)291.pdf

Marmiroli M, Pietrini F, Maestri E, Zacchini M, Marmiroli N, Massacci A (2011). Growth, physiological and molecular traits in Salicaceae trees investigated for phytoremediation of heavy metals and organics. Tree Physiology 31 (12): 1319-1334. - doi: 10.1093/treephys/tprogo

Mattina MI, Lannucci-Berger W, Musante C, White JC (2003). Concurrent plant uptake of heavy metals and persistent organic pollutants from soil. Environmental Pollution 124 (3): 375378. - doi: 10.1016/S0269-7491(03)00060-5

Panich-Pat T, Upatham S, Pokethitiyook P, Kruatrachue M, Lanza GR (2010). Phytoextraction of metal contaminants by Typha angustifolia: interaction of lead and cadmium in soil-water microcosms. Journal of Environmental Protection 1 (4): 431.

Päivöke AE (2002). Soil lead alters phytase activity and mineral nutrient balance of Pisum sativum. Environmental and Experimental Botany 48 (1): 61-73. - doi: 10.1016/Soog8-8472(02)0001 1-4

Rascio N, Navari-Izzo F (2011). Heavy metal hyperaccumulating plants: how and why do they do it? And what makes them so interesting? Plant Science 180 (2): 169-181. - doi: 10.1016/j. plantsci.2010.08.016

Ryan J, Estefan G, Rashid A (2007). Soil and plant analysis laboratory manual. International Centre for Agricultural Research in the Dry Areas (ICARDA), Aleppo and National Agricultural Research Centre (NARC), Islamabad, Pakistan, pp. 172.

Salt DE, Smith R, Raskin I (1998). Phytoremediation. Annual Review of Plant Biology 49 (1): 643-668. - doi: 10.1146/annurev.arplant.49.1.643 Santana KB, De Almeida AAF, Souza VL, Mangabeira PA, Silva DDC, Gomes FP, Dutruch L,
Loguercio LL (2012). Physiological analyses of Genipa americana L. reveals a tree with ability as phytostabilizer and rhizofilterer of chromium ions for phytoremediation of polluted watersheds. Environmental and Experimental Botany 80: 35-42. - doi: 10.1016/j.envexpbot.2012. 02.004

Shahid M, Pinelli E, Dumat C (2012). Review of Pb availability and toxicity to plants in relation with metal speciation: role of synthetic and natural organic ligands. Journal of Hazardous Materials 219: 1-12. - doi: 10.1016/j.jhazmat.2012. 01.060

Sharma P, Dubey RS (2005). Lead toxicity in plants. Brazilian Journal of Plant Physiology 17 (1): 35-52. - doi: 10.1590/S1677-04202005000100 004

Sinha P, Dube B, Srivastava P, Chatterjee C (2006). Alteration in uptake and translocation of essential nutrients in cabbage by excess lead. Chemosphere 65 (4): 651-656. - doi: 10.101 6/j.chemosphere.2006.01.068

Stiborová M, Ditrichová M, Brezinová A (1987). Effect of heavy metal ions on growth and biochemical characteristics of photosynthesis of barley and maize seedlings. Biologia Plantarum 29 (6): 453-467. - doi: 10.1007/BF02882221

Tognetti R, Cocozza C, Marchetti M (2013). Shaping the multifunctional tree: the use of Salicaceae in environmental restoration. iForest 6: 37-47. - doi: 10.3832/iforo920-006

Wang J, Chen C (2009). Biosorbents for heavy metals removal and their future. Biotechnology Advances 27 (2): 195-226. - doi: 10.1016/j.biotech adv.2008.11.002

Wilkins D (1978). The measurement of tolerance to edaphic factors by means of root growth. New Phytologist 80 (3): 623-633. - doi: 10.1111/j. 1469-8137.1978.tb01595.x

Yoon J, Cao X, Zhou Q, Ma LQ (2006). Accumulation of $\mathrm{Pb}, \mathrm{Cu}$, and $\mathrm{Zn}$ in native plants growing on a contaminated Florida site. Science of the Total Environment 368 (2): 456-464. - doi: 10.1016/j.scitotenv.2006.01.016

Yousefi M, Ehteshami M, Sadrnejad S (2015). Lead contamination and pollution indexes in roadside soil in Tehran Iran. Iranian Journal of Health Sciences 3 (4): 8-23. [online] URL: http:// jhs.mazums.ac.ir/article-1-335-en.pdf

Zaier H, Ghnaya T, Rejeb KB, Lakhdar A, Rejeb S, Jemal $F$ (2010). Effects of EDTA on phytoextraction of heavy metals ( $\mathrm{Zn}, \mathrm{Mn}$ and $\mathrm{Pb}$ ) from sludge-amended soil with Brassica napus. Bioresource Technology 101 (11): 3978-3983. - doi: 10.1016/j.biortech.2010.01.035

Zayed A, Gowthaman S, Terry N (1998). Phytoaccumulation of trace elements by wetland plants: I. Duckweed. Journal of Environmental Quality 27 (3): 715-721. - doi: 10.2134/jeq1998.004 $72425002700030032 x$ 